\title{
PHLDA2 Gene
}

National Cancer Institute

\section{Source}

National Cancer Institute. PHLDA2 Gene. NCI Thesaurus. Code C20898.

This gene is putatively involved in the regulation of placental growth. 